\title{
The "Water Bill" Proposed by the Conser- vation Commission of California
}

$7 \mathrm{HE}$ Conservation Commission of California was created in the Legislature laws, statutes, and constitutional amendments revising, systematizing, and reforming the laws of this State upon forestry, water, the use of water, water power, electricity, electrical and other power . . . . " It has prepared a draft of an act providing for a "Water Commission" to con-. trol the appropriation of water and to ascertain existing water rights.

The office of State Engineer was established by the California Legislature in 1878 for "the acquirement of data upon which the State might formulate a policy and frame legislation respecting irrigation matters." ${ }^{2}$ Although the office continued for ten years and assembled much valuable data, it was unsuccessful in securing any new legislation.

In 1900 the California Water and Forest Association in cooperation with Irrigation Investigations of the United States Department of Agriculture made a study ${ }^{3}$ of water right conditions on eight typical California streams, and in 1902 prepared a draft of a "water code" for submission to the Legislature of 1903. The antagonism to the proposed bill was so bitter that it was not introduced.

Although earlier efforts have failed, it has been generally recognized that Legislation regarding water rights is necessary to a businesslike development of the water resources of the State. The only statutes bearing upon the priority of water

1 Calif. Stat. 1911, p. 822.

2 Irrigation Development, William Ham Hall, State Engineer (1886), Pt. 1, p. 12 .

3 U. S. Dept. Agr., Office Exp. Sta. Bu1l. 100. 
rights are Sections 1410 to 1422 of the Civil Code, adopted in 1872. The posting of notices, provided for in Section 1415, had previously been a custom in the mining districts, and was suggested by the posting of notices on mineral claims. In the latter use it served its purpose, but when the length and character of banks of the ordinary stream are considered, the absurdity of perpetuating such a custom for water claims must be apparent.

California has never legislated regarding the adjudication of water rights. Suits in regard thereto follow the same procedure as other civil actions and are most frequently between but two claimants or ditch owners, although there may be a dozen or more diverting the water of the stream. It is therefore possible to have as many actions as the number of ditches will allow combinations of two. It is true that the rights on a number of Southern California streams have been finally established, but it has been the result of many years of expensive litigation, and in no case were all the rights settled in a single proceeding.

Furthermore California has never provided legislation for the distribution or apportionment of water according to decrees. As a result, successful litigants have been forced to secure their rights by contempt proceedings or by force, and every old irrigated community affords many examples of the latter.

So far as water right legislation is concerned, all of the western States were once in the position California is now. Most of them have considerably advanced, and their progress has been along the three following lines: first, the acquirement of rights; second, the determination or adjudication of existing rights; and third, the distribution of water among those entitled to its rise. Before commenting on the bill recommended by the Conservation Commission, a brief analysis will be made of the legislation in other States.

\section{The Acquirement of Water Rights}

1. Wyoming.-The California practice of posting notices was at one time adopted in every western State. Wyoming was the first to make any advance, and in so doing established a system which in general outline is the model today. Its constitution, adopted in 1890 , provides for the division of the State into four divisions with a division superintendent at the head of 
each, for the office of state engineer, and for a board of control to be composed of the state engineer, as president, and the four division superintendents. The board is given "supervision of the waters of the State and of their appropriation, distribution, and diversion."

The statutes adopted in 1890 require an intending appropriator to make application to the state engineer for permission to make the appropriation. The application is made on a blank form furnished by the state engineer, and among other things must state the location and description of the proposed ditch, the time within which it is proposed to begin construction, the time required for completion of construction and the time required for complete application of water to proposed use. If for irrigation, the application must also give the legal subdivisions of land proposed to be irrigated. The state engineer must approve all applications made in proper form and for beneficial purposes except where there is no unappropriated water, or where the proposed use conflicts with existing rights, or threatens to prove detrimental to the public interest - in which cases he must reject the application. If approved, the application will be so endorsed and returned to the applicant and constitutes his authorization to begin construction and perfect the appropriation.

In cases of application for in excess of 25 second feet, or to reclaim over 1000 acres, the state engineer, before acting on the application, may require additional information in regard to the financial ability and the good faith of the applicant. In the endorsement of approval on the application it is required that actual construction must begin within one year from date of approval and that construction must be completed within five years. The state engineer has authority to limit the construction period and the period required for application to beneficial use to a less time than asked for, and also, for good cause shown, to extend the time for the completion of works under an issued permit. Any party may appeal from any action taken by the state engineer to the board of control, and from an action by the board to the District Court.

The statutes do not provide the nature of the proof to be submitted by the appropriator upon the completion of the works, and upon the complete application to beneficial use other than that it shall be "made to appear to the satisfaction of the 
board of control that any application has been perfected in accordance with such application, and the endorsement thereon." On such a showing the board must issue a certiflcate setting forth the amount of the appropriation and the number and date of priority thereof, which date shall be that of filing the application in the office of the state engineer.

2. Idaho and Utah.-The Wyoming method of controlling the acquirement of rights was adopted in Nebraska in 1895 and in Idaho and Utah in 1903. Practically no change, except in the abbreviation of text of statute, was made by Nebraska, but both Idaho and Utah introduced details worthy of comment.

As the Idaho constitution provides that "The right to divert and appropriate the unappropriated waters of any natural stream to beneficial uses, shall never be denied," the right of rejecting applications deemed detrimental to the public welfare, etc., has not been delegated to the state engineer, but he must approve all applications made in proper form and contemplating application to beneficial use. The maximum time allowed to complete the construction of works is five years and that for applying water to beneficial use four years in addition thereto. The state engineer has no authority to extend the maximum time allowance. It is further required that one-fifth of the construction work shall be completed in one-half the time allowed. For appropriations not in excess of 25 second feet construction work must be commenced within sixty days of issuance of the permit, and for other appropriations a bond in an amount to be fixed by the state engineer, not exceeding $\$ 10,000$, must be filed within the said sixty days with the state engineer as a guarantee that the work will be completed as provided in the permit. A regular procedure for proofs of completion of construction and also proofs of complete application to beneficial use is provided. A special procedure for the cancellation and voiding of permits by the state engineer was adopted in 1909 .

In Utah the application contains the additional information of "the time during which it (the water) is to be used each year" - that is, the right is, or may be, restricted to certain periods within the year. A notice of the application must be published for thirty days in a newspaper of general circulation within the watershed, so that a protest may be made to the state engineer by parties claiming prospective injury and thus assist him in determining whether the new appropriation will 
conflict with existing rights. The 1903 statute provided for a hearing in case of protests, but in 1904 such a proceeding was restrained by a district court." No appeal was taken to the Supreme Court and the provision was omitted when the law was re-enacted in 1905.

In 1905 statutes were passed in New Mexico, North Dakota, Nevada, Oklahoma, and South Dakota introducing the Wyoming method and also providing for the publication of the notice and hearings of protests as in Utah and for proofs of completion as in Idaho. The 1909 Oregon statute is identical with that of Wyoming on this point.

3. Interpretation of New Legislation Regarding Acquirement of Rights.-Following the early California cases, ${ }^{5}$ it has been the accepted rule that a valid appropriation of water can be made without following the statutes providing for the posting of notices of appropriation. The new legislation aims to make the statutory method exclusive - the diversion of water except by virtue of an approved application being generally declared unlawful. The question has thus far been before the Supreme Court of Idaho only. In three recent cases ${ }^{6}$ that court held that the old rule still applies, and that an appropriation may be made by actual diversion without applying to the state engineer for a permit. By following the statute, the benefits of the doctrine of relation are secured and the priority of the right is fixed as the date of the filing of the application. When the statute is not followed, the priority dates from the completion of the work and the application to beneficial use. As a practical matter, therefore, no project of any size will be undertaken except under permit from the state engineer. Not only would it be impossible to finance a project with no evidence of a water right, but no rights of way over government land can be secured without such. On the other hand, small ditches are often constructed by farmers who do not apply for a permit, and their right should be protected.

Although the right of the state engineer to reject an appli-

4 Fifth Biennial Rep. (State Engineer of Utah), p. 32.

5 De Nicochea v. Curtis (1899), 80 Cal. 397, 20 Pac. 563, affirmed in 22 Pac. 198; Wells v. Mantes (1893), 99 Cal. 583, 34 Pac. 324.

${ }^{6}$ Nielson v. Parker (1911), 19 Ida. 727, 115 Pac. 488; Youngs v. Regan (1911), 20 Ida. 275, 118 Pac. 500; Furey $\dot{v}$. Taylor (1912), 127 Pac. (Ida.) 678 . 
cation which he deems detrimental to the public welfare was denied by a district court in Utah, ${ }^{7}$ it has been upheld by the Supreme Courts of New Mexico ${ }^{8}$ and Oregon. ${ }^{9}$

The constitutionality of the Idaho act of 1909 , providing a special procedure for the cancellation and voiding of permits by the state engineer, was questioned in Speer v. Stephenson, ${ }^{10}$ on the ground that it confers judicial power upon the state engineer and that the procedure prescribed is not due process of law. The court held that "the granting as well as the cancellation and voiding of permits are acts of administration and clearly within the power which may be given to the state engineer in supervising and administering the law regulating the appropriation of the public waters." The sufficiency of the procedure was also upheld.

\section{Adjudication of Water Rights}

There are two general methods for the adjudication or determination of rights recognized in the statutes fixing a special procedure therefor. In Colorado, Idaho, New Mexico, North Dakota, Oklahoma, South Dakota, and Utah, the adjudication is made by the regular courts. In Wyoming, Nebraska, and Nevada, the determination is made by the board of control or the state engineer. In Oregon the determination is first made by the board of control and then affirmed or modified by the Circuit Court.

1. The Court Method.-In 1879 Colorado was divided by legislative enactment into water districts - the boundaries of each being in most cases fixed to include the entire drainage basin of one or more creeks, but not of an entire river. A special procedure for the adjudication of irrigation water rights was adopted at the same session, providing for the filing of sworn statements by all claimants of an interest in a ditch or reservoir within each district with the clerk of the District Court having jurisdiction, and the initiating of an adjudication by petition of one of more claimants. After due notice, the evidence is taken

7 Fifth Biennial Rep. (State Engineer of Utah), p. 31.

8 Young v. Hinderlider (1910), 15 New Mex. 666, 110 Pac. 1050 (1911).

- Cookinham v. Lewis (1911), 58 Ore. 484; 114 Pac. 88; 115 Pac. 342.

10 (1909), 16 Ida. 707, 102 Pac. 366. 
in open court before the judge thereof, or the latter may appoint a referee to report the evidence and to prepare the findings of fact and form of decree. The details for service of notice and the facts to be ascertained by the referee are set forth in the statute.

The Colorado adjudication is a proceeding in rem, and all persons are forever barred from setting up any claim adverse to its effect. ${ }^{11}$ The objection to it is that the districts are not entire stream systems, so that the rights to only part of a stream are before the court in a single action. From the standpoint of public policy the method is defective in that the State is not represented. No provision is made for the submission of physical data (capacity of ditches, irrigated area, duty of water, etc.), by the state engineer, and as a consequence the early decrees were generally excessive ${ }^{12}$ - often fixing rights for amounts of water over twice the maximum capacity of the ditch.

The other States adopting the court method have profited by the experience of Colorado, and have provided for the adjudications of all claims to the waters of an entire stream system in one action, and for the assembling of all necessary hydrographic and other physical data by the state engineer.

Under the system adopted in Utah in 1903, the adjudication of rights is initiated by the state engineer making a complete survey of the "river system or water source" and collecting all necessary data. After completion of survey a statement is filed with the clerk of the District Court, who mails form for statement of claim to each claimant. The state engineer tabulates the claims and files such with clerk of court. The court may appoint a referee to take further testimony. The decree is rendered by the court based on the maps and data of state engineer, the statements of claims, and the testimony taken before the referee. A certificate is issued to each owner in accordance with the decree.

Under the system ${ }^{13}$ adopted in North Dakota, Oklahoma, Pac. 755.

12 U. S. Dept. Agric., O. E. S. Bull. No. 58, p. 48.

13 The water laws of New Mexico, North Dakota, Oklahoma and 
and South Dakota in 1905, and in New Mexico in 1907, the state engineer makes "hydrographic surveys and investigations of each stream system . . . obtaining and recording all available data for the determination, development and adjudication of the water supply of the State." Upon completion of survey, the state engineer delivers what data is deemed necessary to the attorney general who enters "suit on behalf of the State for the determination of all rights to the use of such water, in order that the amount of unapportioned water subject to disposition by the State under the terms of this act may become known." In any suit over water rights all claimants must be made parties, and when such suit is filed the court shall direct the state engineer to make surveys and assemble the necessary data. The aim of the sections is to allow the state engineer to secure an adjudication of the rights on streams most used for irrigation and also to provide for a complete adjudication on those streams where suit is entered by private parties.

In the "water code" adopted in 1903 in Idaho, it was provided that action could be initiated by a water commissioner for the adjudication of rights to the waters of a stream which had been partly adjudicated. It was also provided that whenever a suit to adjudicate rights is filed the court "shall request the state engineer to make an examination of such stream, and of the canals and ditches diverting water therefrom, and of all the land being irrigated by such canals and ditches and other works," and the map and report resulting from such examination shall be "accepted as evidence in the determination of such rights by such court."

The Idaho provision for the initiation of actions by a water commissioner was declared unconstitutional in Bear Lake Co. v. Budge. ${ }^{14}$ It was held that the statute in question goes beyond the legitimate police power of the State and that "the water commissioner, a public official, is not the real party in interest in a suit to quiet title or to determine adverse interest in property not claimed by or belonging to him or the State."

South Dakota are practically the same as the "Bien Code," which is a draft of an "irrigation code" prepared by Mr. Morris Bien of the United States Reclamation Service. The draft was prepared in 1905 and is similar to the irrigation acts adopted in Idaho and Utah in 1903. 14 (1904) 9 Ida. 703, 75 Pac. 614. 
It was further held that the statutory provision for the service of summons by publication was insufficient.

In Boise City I. \& L. Co. v. Stewart, ${ }^{15}$ the Supreme Court of Idaho held that the section of the 1903 act providing that the court shall request the state engineer to assemble the physical data is merely directory and not mandatory, and "the matter is left in the sound legal discretion of the judge."

2. The Administrative Board Method.-In 1886 the territory of Wyoming adopted the Colorado method of adjudication, but rejected it in 1891 for its present system, under which the determination of water rights is made by the board of control and not by the courts. The board selects a stream on which the rights are to be determined, and fixes a time for the taking of testimony. The state engineer, by an actual survey, assembles all the hydrographic and other physical data necessary to a proper determination of rights. A printed form ("proof of appropriation") is sent to each claimant. Under the present practice, the survey is made by the division superintendent, and the claimant makes the "proof of appropriation" on the completion of the survey of his individual holding. After the completion of the survey of an entire stream and the taking of testimony or "proofs" by the division superintendent, a time and place are fixed by notice duly given, at which the evidence thus assembled shall be open to inspection. A regular procedure is provided for contests and hearings before the division superintendent. After the contests, all the evidence is transmitted to the board of control. At its first regular meeting thereafter. the board examines the evidence and enters an order establishing the priority of water rights. Appeals from the order may be taken to the District Court within sixty days.

The Wyoming method for the determination of rights was adopted in Nebraska in 1895 and in Nevada in 1903. It is foreign to the old idea that only a regular court should pass upon such matters. A suggestion for its adoption in other States generally causes consternation, but an examination of the cases shows that the courts have not viewed it as revolutionary.

15 (1904) 10 Ida. 38, 77 Pac. 25. 
The constitutionality of such statutes was first considered by the Supreme Court of Wyoming, in Farmers Invest. Co. v. Carpenter, ${ }^{16}$ in which case the five following points had been reserved for the decision of the Supreme Court: "First. Is the board of control of the State of Wyoming, provided for by Article $8, \S 2$, of the constitution of Wyoming, vested with judicial power, in such manner that it may adjudicate and determine the rights of priority among claimants to the use of water for beneficial uses from the public streams of this State? Second. Is chapter 8 of the Laws of Wyoming of 1890-91, the same being an act entitled 'An act providing for the supervision and use of the waters of the State,' or the sections of said chapter which authorize the board of control to adjudicate water rights, and providing a system of procedure therefor, constitutional? Third. If the board of control be a legal tribunal for the adjudication of water rights, and the act in question constitutional, are such provisions retroactive, and are claimants of prior rights to the use of water, which were acquired prior to the adoption of the constitution and passage of the acts in question, required to submit their rights to the adjudication of said board? Fourth. In case claimants of water rights which accrued, as stated in the petition herein, before the adoption of the constitution, do not submit their rights to said board for adjudication when proceedings are had under the provisions of the act by the board of control for the adjudication of the rights of the stream out of which said claimants take their water, are they then concluded or estopped by such adjudication? Fifth. Do the provisions of the statute providing for publication of notice and notice by mail, and without actual citation or service of summons, constitute due process of law, whereby the titles of persons to water rights for beneficial uses may be determined?"

The statute was upheld on every point excepting the fourth, regarding which it was said: "The jurisdiction of the courts remains as ample and complete after as well as before an adjudication by the board. But the principle applies here, as in 
other cases, that a party may not relitigate a question which has passed into final adjudication. And the courts will not assume, in an independent action, to determine anew the rights of parties, which, as between themselves, have been settled by the decree of the board of control,- at least, in the absence of fraud, or a showing of facts sufficient to vitiate a judgment. Under the statutes now in force, there being no provision expressly barring or estopping a claimant failing to participate in the adjudication proceedings, and the decree not being res judicata of the undetermined rights of such a claimant, he is at liberty to assert and maintain those rights in the courts, through the regular medium of some form of procedure recognized by the law for the redress of grievances, or the granting of appropriate relief."

The court commented on the new method as follows: "In the development of the irrigation problem under the rule of prior appropriation, perplexing questions are continually arising, of a technical and practical character. As between an investigation in the courts and by the board, it would seem that an administrative board, with experience and peculiar knowledge along this particular line, can, in the first instance, solve the questions involved, with due regard to private and public interests, conduct the requisite investigation, and make the ascertainment of individual rights, with greater facility, at less expense to interested parties, and with a larger degree of satisfaction to all concerned."

It is often claimed that the decision in Farmers Invest. Co. v. Carpenter, supra, cannot be considered a precedent elsewhere, as supervision of the waters of Wyoming is vested in the board of control by constitutional provision. The decision specifically holds, however, that "there exists no difference between claimants whose rights accrued prior to, and those acquiring after, the adoption of the constitution."

The Nebraska statute on this point has been repeatedly upheld, the leading cases being Crawford Co. v. Hathaway, ${ }^{17}$ Farmers Canal Co. v. Frank, ${ }^{18}$ and Enterprise Irr. Dist. v. Tri-State 
Land Co. ${ }^{19}$ Those sections of the Nebraska act of 1895 dealing with the determination of rights are extremely brief and commit to the state board of irrigation the duty of prescribing the details of procedure. Regarding such sections it has been held that "the fact that the method of procedure was not embodied in the statute does not render due process lacking in the proceedings." 20

The powers of the state board "are quasi-judicial in their nature, and an adjudication by it of a right of priority of appropriation of water made before taking effect of the act of 1895, after proper notice, is final unless appealed from and cannot be collaterally attacked." 21

3. The Oregon Method.-In 1909 Oregon adopted section by section ${ }^{22}$ the Wyoming method up to and including the order of the board of control determining the rights. A new step was added providing that the order, and the evidence on which it is based, be submitted to a Circuit Court, having jurisdiction, to be affirmed or modified. In a measure the two methods are thus combined.

The Supreme Court of Oregon has not passed on the constitutionality of the sections providing for the new system of determining rights, but the United States District Court for Oregon recently commented upon them. ${ }^{23}$ The case did not involve the question of constitutionality, but simply that of removing the cause from the board of control to the federal court. It was held that the proceeding before the board is not an action within the meaning of the removal statute. Regarding the new system the Court said: "I am also impressed with the soundness of the view that a proceeding for the adjudication and determination of the rights to the use of the waters within the State, instituted and conducted as provided

19 (Oct. 18, 1912), 138 N. W. (Neb.) 171.

20 Enterprise Irrig. Dist. v. Tri-State Iand Co. (1912), 138 N. W. (Neb.) 171.

21 Farmers Canal Co. v. Frank (1904), 72 Neb. 136, 100 N. W. 286.

22 The only noteworthy change is that the Oregon statute provides that the determination of rights shall be initiated by the petition of one or more water users, while the Wyoming statute authorizes the board of control to begin the determination on the streams most used for irrigation.

${ }^{23}$ In the matter of the determination of the relative rights to the waters of the Silvies River and its tributaries. (Decided Oct. 16, 1912.) 
in the legislative act of 1909 , is in effect a proceeding on behalf of the State through an administrative or executive board to have judicially settled in an economical and practical way the rights of various claimants to the use of the waters of a stream or source of supply, and thus avoid the uncertainty as to water titles and the long and vexatious controversies concerning the same which have heretofore greatly retarded the material development of the State."

4. Results Accomplished.-As viewed from the practical standpoint, the argument is entirely in favor of the administrative board method (including the Oregon method). Excepting Colorado, where the system is clearly defective, practically nothing has been done in the States adopting statutes providing for the adjudication by a regular court after the preparation of physical data by the state engineer. Very decided progress has been made in Nebraska, Nevada and Wyoming, where the rights are determined by the board of control or the state engineer, and the recent work done by the board of control in Oregon is surprising to even the champions of the movement. ${ }^{24}$

\section{Distribution of Water}

Colorado in 1879 introduced a system for the apportionment of the waters of a stream among ditch owners in accordance with decreed priorities, which is the accepted type of this phase of water right legislation. The State is divided into five divisions along drainage lines and a division engineer appointed by the Governor to supervise the work of distribution in each. In immediate charge in each district is a water commissioner. appointed by the Governor from a list of persons recommended by the boards of county commissioners interested. The water

24 "Water users having rights which were initiated under the old laws are eager to have such determined and recorded under this new law, so that the benefits of State police supervision can be secured. Ninety-one petitions requesting such determinations have been filed with the Board of Control. The first step is a survey by the State Engineer. Such surveys have been completed on twenty-three stream systems involving 265,055 acres, or about forty per cent of the total irrigated area of the State. Approximately 2000 claims to water have been filed in these adjudications, and complete determinations made on fifteen stream systems affecting 965 separate rights to water. All this has been accomplished in three years' time, at small cost to the water users and without a single appeal to the Supreme Court."-Bull. No. 2, Office of the State Engineer, Salem, Oregon, April 15, 1912. 
commissioner is authorized to regulate the ditch headgates within his district to satisfy the earlier rights, and may also limit the diversion of water where such is being wastefully used. The water commissioner does not begin work in any irrigating season until called upon by the division engineer or two or more persons controlling ditches within his district. $\mathrm{He}$ is paid, by the counties served, a per diem when actually employed. The division engineer is paid an annual salary by the State.

The Colorado system of distribution was adopted by Wyoming in 1890 , by Nebraska in 1895, by Idaho, Nevada and Utah in 1903, by New Mexico, North Dakota, Oklahoma and South Dakota in 1905, and by Oregon in 1909. The title, incidental duties, method of appointment and payment of the officers involved differ in the States enumerated, but the underlying principle is the same. The aim is to have the State control diversions from streams, in accordance with established rights.

This phase of the new legislation was recently exhaustively analyzed by the Supreme Court of Wyoming in Hamp v. State, ${ }^{25}$ in which many Colorado and Wyoming decisions upholding such statutes were reviewed with approval. The Court said: "By such supervision no rights of private property are invaded, but under the police power of the State, in the interest of the public welfare, and for the protection of private as well as public rights, property intended to be used for no other purpose than that of diverting public waters is regulated; and it is a mistaken notion that through such regulation private property is taken for either public or private use, within the meaning of the constitutional provision prohibiting such taking without just compensation."

Water commissioners in regulating ditch headgates must be guided by the particular class of adjudication or determination designated.in the statutes creating their office, and they have no authority to interfere with ditches on any other basis. ${ }^{26}$

The Water Commission's Bill

The bill proposed by the Conservation Commission pro-

25 (1911), 118 Pac. (Wyo.) 653.

${ }^{28}$ Ryan v. Tutty (1904), 13 Wyo. 122, 78 Pac. 661; Wattles v. Baker Co. (1911), 59 Ore. 265, 117 Pac. 417. 
vides for the acquirement of rights and the adjudication of rights, but is silent regarding the distribution of water. The reasons for this omission cannot be conjectured. There is little use in securing an adjudication unless properly authorized officials are charged with the regulation of headgates in accordance therewith.

It is the belief of students of this subject that the final purpose of the new legislation is the delivery of the water to those entitled to its use - the other features of the statutes being but incidental. ${ }^{27}$ Many judges have insisted that the parties to a suit should share in the payment of the salary of a commissioner appointed by the court to distribute the water according to the decree. The Supreme Court of the United States in passing upon a case from Arizona approved such action of the District Court " in view of the absence of legislative action on the subject and of the necessity which manifestly existed for supervising the use of the stream. . . . ."28

Section 1 of the proposed bill creates a State Water Commission to consist of five members - two ex-officio, the Governor and the state engineer, and three to be appointed by the Governor for a term of four years. The appointed members shall receive a per diem when actually employed - the total annual compensation of any member not to exceed $\$ 5000$.

The section is objectionable in that no qualifications are prescribed for the appointed members, and they are not required to give their full time to the office. If the section be adopted as recommended, commissioners will be appointed who will leave the important duties to secretaries and other assistants. In other States the president of the board corresponding to the suggested commission is the state engineer, and the other members are the division superintendents. (In Nebraska and Nevada the board of irrigation has as members other State

${ }^{27}$ U. S. Dept. Agr. O. E. S. Bull. No. 168, p. 7.

${ }^{28}$ Montezuma Canal Co. v. Smithville Canal Co. (1910), 218 U. S. 371. 
officers, but the state engineer in each case is the responsible executive.) The property rights involved in the suggested measure are so vast that only men of experience in irrigation or other hydraulic work should be eligible.

Section 10 authorizes the commission to investigate stream systems, in order to ascertain the waters actually appropriated. The language of the section is broad enough to cover all vested rights, but the intention of those preparing the draft is probably to give authority to examine the claims to water evidenced by recorded notices. Section 13 authorizes the commission to prescribe the time within which the appropriation must be perfected, upon the application of a claimant who had initiated his right by posting a notice prior to the passage of the act.

Under proper legislation all bona fide claimants of unperfected rights should willingly place their works under the protection of a central office, but the State has nothing to gain by expending money in an extended investigation of the old claims filed. Many thousands of them have been recorded and but few have value, as reasonable diligence in construction work has not been exercised. The investigation of the claims to the waters of any stream, not being adjudicated in full, should be left to the new appropriator directly interested. Under recent decisions he has the right to quiet title. ${ }^{29}$

Section 11 attempts to define "unappropriated water" and uses the expression "ceased to be put" to some useful purpose. The proposed section does not eliminate the present necessity of showing an intention to abandon. Other States have solved this difficulty by declaring the period of non-use which shall constitute a forfeiture.

Section 12 provides that the prescribed method of acquiring rights is the only permissible one, and Section 42 makes it a misdemeanor "to use, store, or divert any water until after the issuance of a permit." As stated above, such provisions, if upheld, may result in undue losses to the small appropriator.

Sections 16 to 24 prescribe the method of acquiring rights and the authority of the commission in regard thereto. The

29 Inyo Consol. Water Co. v. Jess (1911), 161 Cal. 516, 119 Pac. 934; Merritt v. Los Angeles (1912), 161 Cal. 516, 120 Pac. 1054. 
principal objection to the sections is that the language is often ambiguous. Under existing law, rights to the use of water (except for power purposes in California and Oregon), are limited to beneficial use only and not to specified periods. In Section 18 it is provided that "said approval . . . shall give the right to take and use the amount of water for the period allowed by said commission in the approval of such application". . . Section 21 prescribes a license not longer than forty years for power purposes, and for other uses a license effective only for the period of actual use. Section 22 grants a preference right of renewal to all licensees under specified conditions. It does not restrict the renewal to licenses for power purposes only. The interpretation must therefore be that even irrigation rights are to be limited to periods fixed by the commission. Such an idea is positively repugnant to the irrigation policy of the country.

Licenses to divert water for power purposes were restricted to twenty-five years by an act of the California Legislature at the regular session in 1911, but the period was changed to forty years at the special session of 1911-12. The only other irrigation State limiting such rights is Oregon. ${ }^{30}$ Before much was known of the power of the State to regulate the rates of public service companies there may have been some excuse for such legislation. There is none now.

In this connection the recommendations of a Committee on Water Power, Forestry and Drainage of the Wisconsin Legis-

30 Regarding the Oregon legislation, State Engineer Lewis in his Third Biennial Report (1909-1910, pages, 82, 83), says:

"The annual tax idea seems to be based upon the fact that water is the property of the public, and those who enjoy a right to its use should pay something to the State for the privilege. It was not recommended or approved by the Oregon Conservation Commission. Whether the basis for electric power charges will be to "charge all the traffic will bear,' as in railway rates, is a matter of uncertainty. The price of electric power is being constantly lowered through competition with steam producer gas, etc., where the cost of production has been greatly reduced in recent years through improvements in methods and machinery. Only those water powers will be developed where the cost of production will permit successful competition with these other powerproducing agencies. If, in addition to the necessary development cost a heavy annual charge per horsepower must be paid the State, it is conceivable that such charge may defeat rather than promote the conservation idea, as well as retard development. We will be consuming our limited supply of coal, for economic reasons, while our water power remains undeveloped and goes to waste year after year." 
lature (1910) is of interest. The committee was dealing with the navigable streams only, as in Wisconsin the rights on those not navigable belong to the riparian owners. The following is an extract from the report:

"Your committee is unanimous in believing, and recommends that, in the interest of the public welfare, all franchises granted to create water power should be indeterminate, the same as in the case of other public utilities. This insures to the public lower rates and faster development of our resources, and at the same time the public, through a system of reasonable regulation by the Wisconsin Railroad Commission, is safeguarded against extortion by those who sell power. . . . In the interest of the public welfare, and in order to prevent over-capitalization, through an unearned increment, no element of value should ever be given to any permit, license or franchise granting authority to erect and maintain a dam in navigable waters for the development of hydraulic power or other purposes."

It is certain that California will be greatly benefited by substituting an indeterminate license, to divert water for power purposes, for the present fixed term license. It has been recommended by a committee of the Commonwealth Club of California that the indeterminate license be granted subject to the condition that the works may be taken over at any time by the State or other public unit at a valuation to be fixed by the Railroad Commission, and subject to the further condition that the water right thus secured cannot be capitalized for either rate fixing purposes or in cases of purchase by the State or other public unit.. ${ }^{\text {s1 }}$

Section 24 fixes the fees to be paid when applications are filed and also the annual charges after the issuance of the license. Every State which has adopted the new legislation has a schedule of fees for the granting of permits, licenses, etc., but none (excepting Oregon for power purposes). levy an annual charge. The only service the State can render after issuing the license is to distribute the water, and, as stated, this service is not proposed in the bill.

s1 Transactions of the Commonwealth Club of California, Vol. VII, No. 2, p. 79. 
Sections 25 to 40 provide the procedure for the determination of existing rights by the water commission and closely follow the sections of the 1909 Oregon "water code" on this point. The Oregon sections providing for the taking of testimony by the division superintendents are omitted. Section 31 makes the assembling of physical data by the commission discretionary with it. The strength of the Oregon statute lies in the fact that the physical data must be collected by the state engineer. In no other way can the interests of the public be protected.

The Oregon sections provide that while the hearing of the order of the board of control is pending in the Circuit Court, the division of water shall be in accordance with such order. The provision is omitted in the proposed bill.

Section 40 is copied directly from the Oregon statute and provides that the decree shall declare the extent, etc., of the water right, "whether riparian or by appropriation." It is believed that the Oregon statute is defective in providing for the determination of riparian rights, and it is understood that in practice the board of control does not pass upon them.

The Supreme Court of Nebraska in McCook Irr. \& W. P. Co. v. Crews, ${ }^{32}$ expresses the proper attitude of the new legislation as follows:

"It is reasonably clear that the law of irrigation is not specially concerned regarding a plan and method for the taking and distribution of water for irrigation among riparian owners. This right is defined, limited, and controlled by the common law. Of course, the right is recognized, and the law will guard and protect such rights as all other property rights are guarded and protected."

The reasons for restricting the statutory determinations to appropriation rights are especially potent in California, where the law has been laid down as follows: "The doctrine that a riparian owner is limited to a reasonable use of the water applies only as between different riparian proprietors. As an appropriator who seeks to divert water to nonriparian lands, the riparian owner is entitled to restrain any diversion which

3270 Neb. 115, 102 N. W. 251 (1905). 
will deprive him of the customary flow of water which is or may be beneficial to his land. $\mathrm{He}$ is not limited by any measure of reasonableness." ${ }^{33}$

Section 41 follows the new legislation in making water for irrigation purposes appurtenant to land, and in providing for the transfer of the right to other land under certain conditions. Other States provide a regular procedure before the state engineer for this transfer.

Section 43 forbids the change in use of water except under a new appropriation. As the right to change the use without interfering with other rights has been considered vested, ${ }^{34}$ the section would undoubtedly be held unconstitutional.

Section 44 provides that none of the provisions of the act "shall apply to any city . . . municipal water district, or lighting district." It is customary to grant preferential rights to municipalities for domestic water supply, but it is in the interest of all public units that their existing rights be determined as other rights are. The section suggests a perpetuation of the custom of posting notices by such public units, for which no reason can be given.

The expression "water or the use of water" is constantly used throughout the bill, indicating that in the minds of the commissioners there is a difference between the two. In a very early California case ${ }^{35}$ it was said: "It is laid down by our law writers, that the right of property in water is usufructuary, and consists not so much of the fluid itself as the advantage of its use. . . . The right is not in the corpus of the water, and only continues with its possession." In view of the above statement of the law, which is always accepted without question, it is believed that no good purpose can be served by the expression. Its incorporation in the statutes will result in much argument as to its interpretation and may mislead a court into holding that by its use the legislature intended to change the accepted law.

\section{Summary}

The "water bill" proposed by the California Conservation

33155 Cal. 59, 99 Pac. 502 (1909).

34 Wiel, "Water Rights in the Western States," $§ 511,512$.

35 Eddy v. Simpson (1853), 3 Cal. 252. 
Commission has many good sections regarding the acquirement of water rights, and the determination of existing rights. These sections have been borrowed from the statutes of other western States where they have rendered excellent service and where they have been upheld in regard to the most serious legal points involved.

The objectionable features of the bill are the provision for a water commission, the qualifications of whose members are not specified; the failure to provide a system for the distribution of water; the use of expressions not sanctioned by existing law; and the introduction of charges and restrictive measures not countenanced by the better legislation elsewhere, and which are repugnant to public policy in the development of our water resources.

A. E. CHANDLER. 